Rusznák, Dóra ${ }^{1}$

\title{
Informed Choices on our Diet: How much we Really Know about Fish
}

\author{
Rusznák Dóra \\ Tudatos táplálkozás, avagy mit is tudunk a halról?
}

Abstract:

The 1169/2011/EU regulation will come into force by the end of the year. The new regulation is more stringent than before, however non-processed foods continue to be exempt from nutrition labelling. At first, it might not seem to be an important issue, yet non-processed foods can contain as many artificial colouring agents and substances as processed food.

Keywords: health conscious diet, informed choices, artificial food colouring agents, salmon

Összefoglaló:

Az év végétöl hatályos 1169/2011/EU Európai Uniós rendelet új kérdéseket vet fel a fogyasztók élelmiszerekkel kapcsolatos tájékoztatásával kapcsolatban. A vonatkozó elöírások számos tekintetben szigorodnak és a korábbinál részletesebb tájékoztatást írnak elö. A nem feldolgozott élelmiszerek azonban továbbra is mentesülnek a tápértékjelölés alól, így például a halakban a takarmányozás során felhalmozódott különbözö segédanyagokról már nem értesülhet a fogyasztó.

Kulcsszavak: egészségtudatos táplálkozás, tudatos fogyasztói döntés, mesterséges színezékek, lazac

In December 12, 2011 a new regulation (1169/2011/EU) came into force on the content of food labels. The regulation shall apply from 13 December, 2014, except for the provisions relating to nutrition, which will be applicable from 13 December 2016. The new regulation consolidates the law across the EU on the required information on food labels, ensures the right of the consumers for information, therefore attempts to enable them to make informed choices about their purchases. The ultimate goal of the legislators was to create a regulation that secures the health protection of consumers by receiving adequate and thorough information on the purchased food. Moreover, the regulation recognizes, that apart from the nutritional data, there are other factors that can influence consumer choices. These factors include environmental, economic, social and

\footnotetext{
${ }^{1}$ Fóiskolai adjunktus, Ph.D., Szolnoki Főiskola Turizmus-, Térség és Társadalomfejlesztési Tanszék, 5000 Szolnok Tiszaligeti sétánv 14
}

ethical considerations (1169/2011/EU (3)). The general principle of food law is to provide consumers with all the needed information to be able to make the most suitable decision for themselves and to prevent any misleading market practice. Although the more rigorous food labelling law and the common regulation across the EU are definitely positive steps forward, these changes raise two questions: it is uncertain to what extent consumers can utilize and interpret the information received, and if consumers get really all the information they need. Is it possible the make an informed choice based on the available information?

Regulation 1169/2011/EU exempts from mandatory nutrition labelling the nonprocessed foods and foods where in all likelihood nutrition labelling would not affect consumer choices (unless it is especially required by EU law). Therefore, it is not required to provide nutritional information 
(only information on origin) for fresh food as meat, fish, milk, vegetables and fruits. Although it seems as a rational exemption, in many cases these foods also contain chemicals and additives that could potentially alter consumer choices.

The artificial colour content of foods must be stated on the food label. However, in case the flesh of a salmon or the egg yolk is coloured through adding colour to the feed- it is not compulsory to provide information on it for the consumer. In this way the consumer is practically misled, believing that the bright colour of the salmon and the egg yolk comes from the quality feed the animals were kept. Even if the given colouring agent is not likely to cause harm, the principle of food law to provide consumers with all the needed information is not met.

The case of salmon could be particularly interesting for those who would like to have a healthy and conscious lifestyle. Fish consumption is very low in Hungary and all diet recommendations suggest eating more fish, especially marine fish. The National Institution of Nutrition (Országos Élelmezés- és Táplálkozástudományi Intézet) recommends eating fish at least once a week (Rodler, 2004: 16). Unfortunately the recommendation does not specify how we should choose among fish and does not mention that the high fish consumption can even have potential health risks. The Institution emphasises the nutritional benefits of fish, especially the omega- 3 fatty acid and vitamin content, but it does not inform consumers on methylmercury and other toxins. Methylmercury is a very harmful toxin and the level of this toxin in the flesh depends highly on what the fish was fed- just as the level of omega-3 fatty acid content. An even more important question is the polychlorinated biphenyl (PCB) content of the fish. PCBs are extremely toxic and can be found in all fish. Farmed fish are not an exception, they can contain these toxic substances even in a higher concentration. These kinds of information are not available for an ordinary consumer, not even if one specifically wants to know about this, let alone during regular shopping.

Without doubt, fish are excellent protein-, vitamin- and mineral sources. Fish consumption is recommended especially due to its omega-3 fatty acid content. Omega-3 fatty acids are not exclusively found in fish, however, they contain it in the highest concentration. The fat found in fish is mostly unsaturated and particularly rich in omega-3 fatty acids, namely eicosapentaenoic acid (EPA) and docosahexaenoic acid (DHA). Omega-3 fatty acids have health benefits and because they are detectable in the brain, it is believed that their presence is critical for the normal brain development in early childhood. Moreover, research has shown that EPA and DHA can prevent the formation of blood clots and heart arrhythmia, therefore protect against heart attacks and strokes. Taking these into account, the American Heart Association (AHA) recommends everyone to have fish at least twice a week. (American Heart Association, 2010).

However, as it was mentioned above, the problem with fish is the toxins they contain. The flesh and fat of the fish undoubtedly contain many beneficial nutrients, but they also accumulate dangerous toxins (mercury, chlordane, dieldrin, DDT, dioxins, PCBs). Due to industrial waste, the rivers, lakes, seas and oceans are all polluted. They contain industrial materials and agricultural pesticides that have been long banned due to their detrimental effect on health. These toxins are accumulated in the fish and the larger and fattier the fish, the higher is its toxin content. In case of a predator fish the toxin level is even higher, because its feed contains toxins as well. One would think that farmed fish are safer to consume, but unfortunately the situation of farmed fish is worse. The farmers feed the fish with other fish and fish oil in order to make them grow faster and bigger. Consequently, farmed fish have an even higher PCB content, because they are fed from their early life with adult fish with a high toxin level. PCBs and 
other similar toxins at high doses can have serious health consequences as skin diseases, birth defects, reproductive disorders or even behavioural problems. Fortunately at an average fish consumption rate, these toxins would not pose a health risk. Therefore, theoretically we should not worry about it, although it does not mean that we should not know about the potential consequences. For a conscious consumption we need to know these kinds of information. From the point of view of the consumer, even if researches stated that a certain level of toxins would not pose health risks, a conscious consumer would still want to opt for another choice of fish with a lower level of toxins. To make an informed choice on fish we need to know its origin, if it is farmed or wild, its position in the food chain and how fatty it is (Nestle, 2006: 216). The new EU regulation seems to give the answer to this problem. From December 14, 2014 the label on fresh fish or the other information tools should state the followings:

- The commercial and the scientific name of the species

- If the fish was caught in fresh water or in the sea, or if it is farmed

- The more specific place of the catch or the place of the farm (FAO subdivision)

- Freshwater fish: if it is from a country within or outside the EU

- Farmed fish: if it was farmed in an EU or non-EU country in the last period of breeding

- The used fishing gear.

In addition to this information retailers may provide other information as well (environmental, production, farming techniques etc.). The European Commission is examining if there is a possibility to set up a standard for bio fish, to satisfy the need for fish with no toxins and harmful chemicals (European Commission, 2014).

From December 2014, the questions regarding fish will be partly answered. Although the new EU regulations are definitely positive steps foreward, still, there is an area where the problem of lack of information remainsartificial colouring. If we buy farmed salmon, its bright and tempting colour is more likely to be from artifical colourants. Breeders usually mix canthaxanthin (E $161 \mathrm{~g}$ ), a permitted colourant to fish feed. Although canthaxanthin is permitted, its use is under strict regulation because its long term effect on health is not certain. The European Food Safety Authority (EFSA) examined its effect on health in 2010 for the last time. Canthaxanthin belongs to carotenoids and it can be naturally found in chanterelles, crustaceans, salmon or even in the feather of flamingos. As colourant, the synthetic version of canthaxantin is used. In a high dose, canthaxanthin can cause crystalline deposits in the retina that may lead to vision damage. Although it is needed in a high amount to cause potential damage, for those people who have an eye disease or retinal degeneration, even a lower amount could have harmful effects (EFSA, 2010). The flesh of a wild salmon is bright red-orange, because they feed on small crustaceans containing pigments (mainly astaxanthin and canthaxanthin). Farmed salmon is fed with other fish and fish oil, so its flesh would be greyish-white. Obviously, consumers would not buy such coloured salmon, so breeders add artificial colourant (synthetic canthaxanthin) to the fish feed. There is even a colour-scale from which breeders can choose to attract the most consumers. The company Hoffman-La Roche offers colourants with synthetic astaxanthin and canthaxanthin from pale salmon pink (\#20) to a bright orange-red (\#34) colour. Focus group research has shown that the consumers love colour \#33 the most, that is the closest to the colour of the wild salmon, and they reject the pinkish colour \#27 (Nestle, 2006: 224-225). Therefore, through artifical colouring, consumers are actually misled, beliving that the fish was wild and was fed crustaceans.

The new 1169/2011/EU regulation brings good changes on food labelling and provides help for the consumers to be able to make more 
informed decisions. However, the legislation is not yet perfect, consumers still do not get all the information they need and cannot access all the information that could potentially alter their consumer choices. The colourants or antibiotics that are added to animal feed is not stated on the label and this question was not even considered during the legisation. Some people argue that too much information would only confuse consumers, therefore it is better not to make this information available (Holland, 2013). This point of view is unacceptable and it would undermine the right of the consumers to information. Consumers should be able to access all the information they need and to prevent misleading market practices, consumers should be educated on how to utilize the given information.

\section{BIBLIOGRAPHY}

[1] American Heart Association. (2010):. „Fish and Omega-3 Fatty Acids” available online: http://www.heart.org/HEARTORG/GettingHealthy/NutritionCenter/HealthyDietGoals/Fishand-Omega-3-Fatty-Acids_UCM_303248_Article.jsp last accessed: 2014. 01. 19.

[2] European Comission (2014): "Marketing of fishery and aquaculture products" available online: http://ec.europa.eu/fisheries/cfp/market/marketing/index_en.htm last accessed: 2014. 01. 20.

[3] European Food Safety Authority (EFSA) (2010): Scientific Opinion on the Re-evaluation of canthaxanthin (E $161 \mathrm{~g}$ ) as food additive. EFSA Journal. available online: http://www.efsa.europa.eu/en/efsajournal/pub/1852.htm last accessed: 2014. 01. 23.

[4] Holland, Jason (2013): "Is Fish Labeling necessary?" available online: http://www.seafoodsource.com/en/commentary/seafoodsource-commentary/24254-isfish-labeling-necessary last accessed: 2014. 01. 20.

[5] Nestle, Marion (2006): What to Eat. New York: North Point Press

[6] Rodler, Imre (2004): „Táplálkozási Ajánlások, Adatok a Tápanyagtáblázatból”, available online:

http://www.oeti.hu/download/taplalkozasi_ajanlasok,_adatok_a_tapanyagtablazatbol.pdf last accessed: 2014. 01. 19. 